\title{
Cephalopoda as prey of juvenile Southern elephant seals at Isla 25 de Mayo/King George, South Shetland Islands
}

\author{
Luciana Burdman', Gustavo A. Daneri', Javier Negrete², Jorge A. Mennucci² \\ \& Maria E. I. Marquez ${ }^{2}$
}

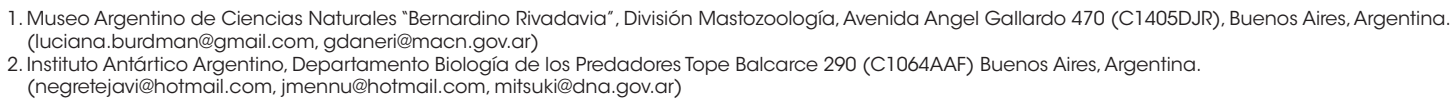

ABSTRACT. The aim of the present study was to enhance the knowledge of the feeding habits of the juvenile component of the population of Southern elephant seals [Mirounga leonina (Linnaeus, 1758)] from Isla 25 de Mayo, South Shetland Islands, age class whose diet information is scarce. A total of 60 individuals were stomach lavaged in the spring - summer seasons of three consecutive years $(2003,2004$ and 2005$)$ of which $53.3 \%(\mathrm{n}=32)$ presented food remnants. The Antarctic glacial squid Psychroteuthis glacialis Thiele, 1921 was the dominant prey taxon in terms of frequency of occurrence $(68.7 \%)$, numerical abundance $(60.1 \%)$ and biomass $(51.5 \%)$, contributing $84.1 \%$ to the total relative importance index. Other squid prey species of importance were Slosarczykovia circumantartica Lipinski, 2001 in terms of occurrence (37.5\%) and numerical abundance (14\%) and Moroteuthis knipovitchi Filippova, 1972 in terms of biomass (16\%). All identified cephalopod prey taxa are distributed south of the Antarctic Polar Front, except for the squid Martialia hyadesi Rochebrune \& Mabille, 1889 which has a circumpolar distribution associated to the Polar Frontal Zone. No significant differences in the sizes of P. glacialis preyed upon by elephant seals were found between sexes and years. However, significant interannual differences were found in the taxonomical composition of their diet. This would be associated with temporal changes in food availability at the foraging areas of seals, which in turn may have been influenced by changes in oceanographic conditions as a result of the El Niño Southern Oscillation (ENSO) phenomenon that occurred during part of the study period. Furthermore, a differential response of males and females to this temporal variation was observed, with the former being also associated to a predation on octopods. This would suggest a sexual segregation in foraging habits of this species from the early stages of its life cycle.

KEYWORDS. Mirounga, diet, Antarctica.

RESUMEN. Cephalopoda como presa de juveniles de elefantes marinos del sur en la Isla 25 de Mayo/King George, Islas Shetland del Sur. El objetivo del presente estudio fue el de incrementar el conocimiento de los hábitos alimentarios del componente juvenil de la población de elefantes marinos del sur [Mirounga leonina (Linnaeus, 1758)] de Isla 25 de Mayo, Islas Shetland del Sur, clase de edad cuya dieta es poco conocida. Un total de 60 ejemplares fueron sometidos a técnicas de lavaje estomacal durante primavera - verano de tres años consecutivos (2003, 2004 y 2005) de los cuales el 53,3\% (n=32) presentaba restos alimentarios. El calamar antártico Psychroteuthis glacialis Thiele, 1921 fue el taxón presa dominante en términos de frecuencia de ocurrencia $(68,7 \%)$, abundancia numérica $(60,1 \%)$ y biomasa $(51,5 \%)$, contribuyendo en un $84,1 \%$ al índice de importancia relativa total. Otros calamares presa de importancia fueron Slosarczykovia circumantartica Lipinski, 2001, en términos de ocurrencia (37,5\%) y de abundancia numérica (14\%), y Moroteuthis knipovitchi Filippova, 1972 en términos de biomasa (16\%). Todos los taxa presa identificados se distribuyen al sur del Frente Polar Antártico, a excepción de Martialia hyadesi Rochebrune \& Mabille, 1889, especie que presenta una distribución subantártica asociada a la Zona del Frente Polar. No hubo diferencias significativas intergenéricas ni interanuales en los tamaños de P. glacialis predados por los elefantes marinos. Sin embargo, se encontraron diferencias interanuales significativas en la composición taxonómica de la dieta. Esto estaría asociado a los cambios temporales en la disponibilidad de alimento en las áreas de forrajeo de los elefantes, que a su vez pudieron estar influenciados por las variaciones en las condiciones oceanográficas, como resultado de la Oscilación Austral del Niño (ENSO) que se produjo durante parte del período de estudio. Por otra parte, se observó cierta respuesta diferencial de machos y hembras a esta variación temporal, estando los primeros asociados a una predación sobre octópodos. Esto sugiere una segregación sexual en los hábitos de forrajeo de esta especie desde etapas tempranas de su ciclo de vida.

PALABRAS CLAVE. Mirounga, dieta, Antártida.

The Southern Ocean is a highly versatile and unpredictable environment, where the variability of oceanographic factors leads to a variation in the distribution, structure and abundance of biological communities. It is one of the most productive of the oceans in the world as a result of the brief and intense phytoplankton blooms occurring during Spring (SMETACEK et al., 2005). Physical processes play an important role in determining the distribution and abundance of organisms in the ocean (РАкномоv et al., 1994; Hunt et al., 1999; Pollard et al., 2002). These provide the physical structure in which phytoplankton and food webs will develop (MANN et al., 1996). More important is the variability and heterogeneity of the physical processes at mesoscale level (Lima et al., 2002), this being applied particularly to the Indian, Atlantic and Pacific sectors of the Southern Ocean subdivided into different regions well marked by fronts (Bost et al., 2009).

Southern elephant seals are opportunistic generalist predators with a broad feeding niche, which annual cycle is a combination of two terrestrial phases (molt and breeding) and two large aquatic phases (post-molt and post-breeding) (Le Boeuf \& Laws, 1994). In these feeding phases, seals make long migrations. They can travel more than 5,000 $\mathrm{km}$ from their breeding and molting areas (MCCONNELL et al., 1992; Hindell \& MCMAHON, 2000; Hindell et al., $2003)$ and dive to great depths $(1,500 \mathrm{~m})$ (HINDELl et al., 
1992). Consequently, they can access to a wide range of topographic and oceanographic conditions in the Southern Ocean. Reserves stored during their aquatic phase are essential to carry out their reproductive efforts on land (Boyd et al., 1994; KNox, 1994; Hindell et al., 2003; Biuw et al., 2007). Southern elephant seal breeding colonies are located mostly around the Antarctic Convergence (LING \& Bryden, 1992; Laws, 1994; Le Boeuf \& Laws, 1994) with four major population cores: Macquarie, Kerguelen, Peninsula Valdes and South Georgia (Slade et al., 1998; Hoelzel et al., 2001). The colony analysed in this study is located at Isla 25 de Mayo, South Shetland Islands and corresponds to the South Georgia stock, in the Atlantic sector of the Southern Ocean. The population at South Georgia has remained stable over the past 45 years (McCANN, 1985; Hindell et al., 1987; Laws et al., 1994; BOYd et al., 1996; BuRTON et al., 1997; GUINET et al., 1999; SCAR, 2002, 2006; McMAHon et al., 2003).

The juvenile survival appears to be one of the determining factors in the demographic dynamics of $M$. leonina (Hindell et al., 1994; MCMAHON et al., 2003), and this is influenced by changes in morphology, behavior and hunting experience during ontogeny (FIELD et al., 2007). Cephalopods (squid and octopus) constitute a common prey in the diet of the southern elephant seal (CLARKE et al., 1982; RODHOUSE et al., 1992; DANERI et al., 2000), although fish have also been reported as a relatively important food item, at least seasonally (DANERI \& CARLINI, 2002; BRADShaW et al., 2003; Newland et al., 2009). The southern elephant seal has a key role as a top predator in the food webs of the southern marine ecosystem. In the Scotia Sea it has been reported that this phocid species accounts for $75 \%$ of the $3.7 \times 10^{6}$ tonnes of cephalopods and $45 \%$ of the 2 $\mathrm{x} 10^{6}$ tons of fish predated by birds and seals in the area (Croxall et al., 1985). In addition, further studies have shown that the contribution of different prey species to its diet may vary with locations, seasons and between sex/ age type (Rodhouse et al., 1992; Green \& Burton, 1993; Slip, 1995; Daneri et al., 2000; PiatKowski et al., 2002; BRADSHAW et al., 2003; vAN DEN HofF et al., 2003; Field et al., 2005; among others).

For the I. 25 de Mayo population of M. leonina, studies have reported that juveniles (in their first year of life), females and adult males develop their foraging activity in different areas of the Southern Ocean (Bornemann et al., 2000; Tosh et al., 2009). Additionally, dietary studies conducted to date on this population, have shown that its diet differs from those of other colonies since it is mainly represented by fish and squid species distributed almost entirely south of the Antarctic Polar Front (DANERI et al., 2000, 2005; DANERI \& CARLINI, 2002; PiatKowski et al., 2002). Nevertheless, it should be noted that dietary information of the juvenile component of M. leonina in the Atlantic Sector of the Southern Ocean is relatively scarce.

It is worth highlighting the total absence of fish remains in the stomach contents of juvenile seals sampled in this study. Therefore, the aims were to (1) examine the cephalopod component of juvenile individuals of $M$. leonina from I. 25 de Mayo colony; (2) assess temporal variations in their cephalopod diet during the study period and (3) analyze differences in cephalopod predation patterns between sexes.

\section{MATERIALS AND METHODS}

The study was carried out from November to December of three consecutive years (2003, 2004 and $2005)$ at Stranger Point $\left(62^{\circ} 14^{\prime} \mathrm{S}, 58^{\circ} 40^{\prime} \mathrm{W}\right)$, Isla $25 \mathrm{de}$ Mayo/ King George (Fig. 1). The sampling area corresponds to an Antarctic Specially Protected Area (ASPA No. 132), located next to "Carlini" Scientific Station (formerly known as Jubany).

Sixty one recently hauled out juvenile Southern elephant seals were immobilized by intramuscular injection of ketamine hydrochloride ( $\mathrm{n}=15$ in 2003; $\mathrm{n}=19$ in 2004 and $\mathrm{n}=27$ in 2005) and subjected to stomach lavage following DANERI \& CARLINI (1996).

In the field, stomach content samples were filtered in a sieve of $1 \mathrm{~mm}$ mesh size. Cephalopod remains, mainly represented by mandibles (beaks) and few eye lenses, were preserved in $70 \%$ ethanol for further laboratory analysis. Beaks were identified using appropriate guides (OKUTANI \& Clarke, 1985; Clarke, 1986; Xavier \& Cherel, 2009) and by comparison with reference collections deposited in the Museo Argentino de Ciencias Naturales "Bernardino Rivadavia" (MACN) and the Instituto Antártico Argentino (IAA).

Once determined, lower rostral length (LRL) (teuthoids), and lower hood length (LHL) (octopods), were measured using a digital caliper (accuracy $0.01 \mathrm{~mm}$ ). From these measurements the mantle length (LM) and the body wet mass (M) were estimated, using published allometric equations (Clarke, 1986; Rodhouse et al., 1990, 1992; XAVIER \& Cherel, 2009). The contribution of the different prey taxa identified was calculated in terms of biomass ( $\%$ $\mathrm{M})$, number $(\% \mathrm{~N})$ and frequency of occurrence $(\% \mathrm{~F})$.

The Index of Relative Importance (IRI) was calculated according to PINKAs et al. (1971), but as a modified version, by replacing the volume percentage by weight percentage according to REID (1995):

$$
\mathrm{IRI}=(\% \mathrm{~N}+\% \mathrm{~W}) * \% \mathrm{FO}
$$

Furthermore, and in order to make easier the interpretation of the IRI, this index was expressed on a percent basis (\%IRI) following CoRTÉs (1997). A three factor nested ANOVA design (year of sampling, seal sex, and specimen sampled) was performed to detect seasonal differences in the sizes of the dominant squid species (Psychroteuthis glacialis) preyed upon by seals. The variable "specimen" was nested within year and sex factors. The model assumptions were corroborated. Finally, to determine whether or not there existed significant differences between years and sexes in the taxonomical composition of the diet, a log-linear analysis was applied. 


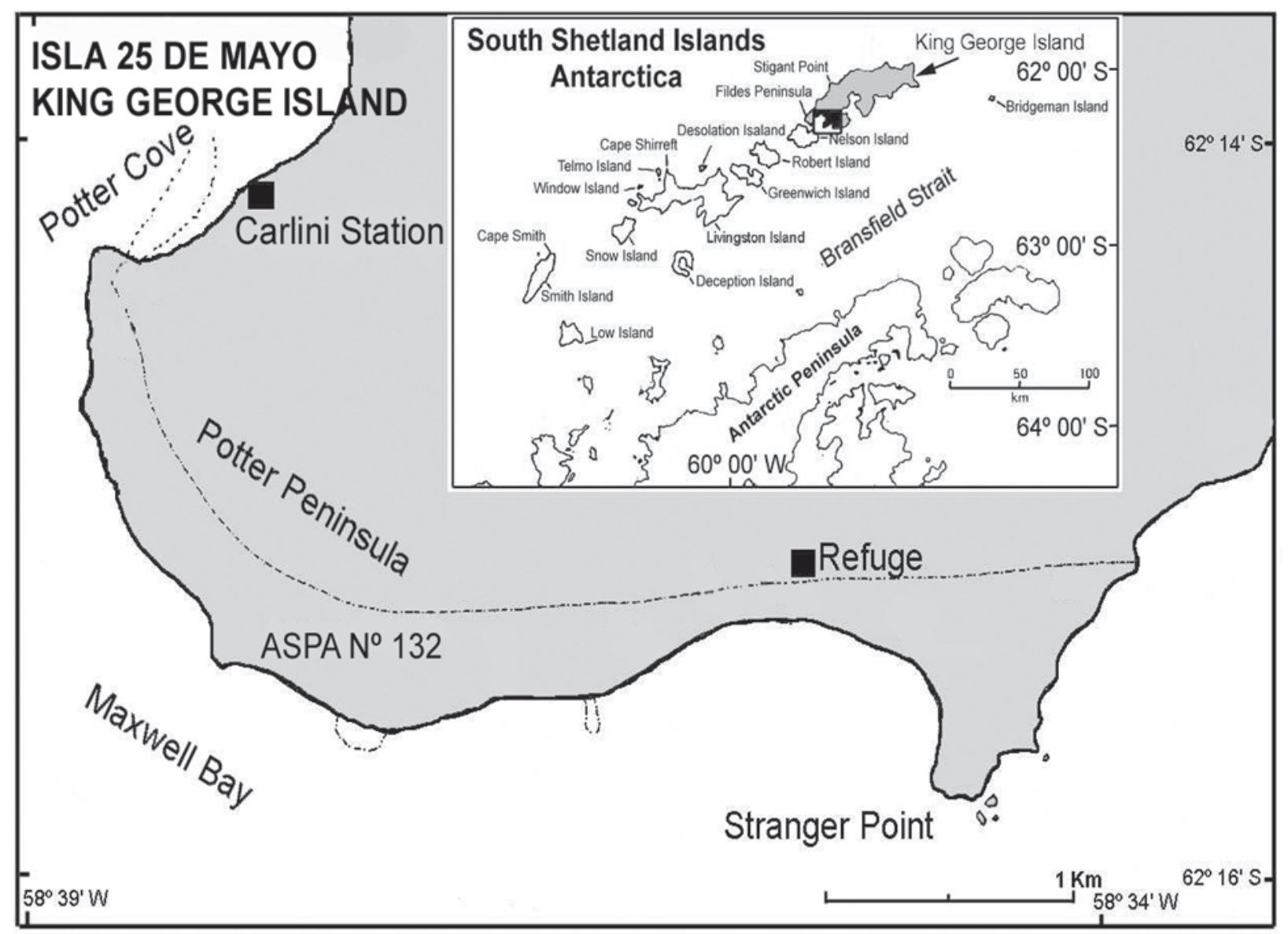

Fig. 1. Study area and its geographical location, South Shetland Islands, Antarctica (modified from CARLINI et al., 2006).

\section{RESULTS}

A total of 356 beaks were extracted from stomach contents (194 lower and 163 upper). Most of these were in a fresh state. Only one of the lower beaks had to be discarded because of its degradation level. The average number of lower beaks found per stomach was 6 (range 1 - 36).

In the total period of the study, 10 taxa were identified ( 7 teuthoids and 3 octopods) (Tab. I). All teuthoid species together accounted for over $99 \%$ of the overall IRI. The predominant prey taxon was the Antarctic glacial squid, Psychroteuthis glacialis, which occurred in $68.8 \%$ of stomach samples and represented respectively $60.1 \%$ and $51.5 \%$ in terms of numbers and mass of the total cephalopods consumed. Moreover, this squid taxon had the highest \%IRI (84.1) followed by Slosarczykovia circumantartica $(6.2 \%)$, both taxa thus accounting for over $90 \%$ of the percentage contribution to the overall IRI.

Tab. I. Taxonomical composition of the cephalopod prey of juvenile Southern elephant seals, M. leonina, expressed in terms of frequency of occurrence $(\mathrm{F}, \% \mathrm{~F})$, numerical abundance $(\mathrm{N}, \% \mathrm{~N})$, biomass $(\mathrm{M}$ grams, $\% \mathrm{M})$ and index of relative importance (IRI, \%IRI).

\begin{tabular}{|c|c|c|c|c|c|c|c|c|c|}
\hline & Prey taxon & $\mathrm{F}$ & $\% \mathrm{~F}$ & $\mathrm{~N}$ & $\% \mathrm{~N}$ & M & $\% \mathrm{M}$ & IRI & $\%$ IRI \\
\hline \multirow{7}{*}{ 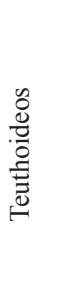 } & Psychroteuthis glacialis & 22 & 68.8 & 116 & 60.1 & 9889.4 & 51.5 & 7669.5 & 84.1 \\
\hline & Slosarczykovia circumantartica & 12 & 37.5 & 27 & 14.0 & 188.2 & 1.0 & 561.3 & 6.2 \\
\hline & Moroteuthis knipovitchi & 5 & 15.6 & 9 & 4.7 & 3080 & 16.0 & 323.3 & 3.5 \\
\hline & Gonatus antarcticus & 5 & 15.6 & 19 & 9.8 & 1581.6 & 8.2 & 282.4 & 3.1 \\
\hline & Alluroteuthis antarcticus & 3 & 9.4 & 10 & 5.2 & 1961 & 10.2 & 144.2 & 1.6 \\
\hline & Martialia hyadesi & 2 & 6.3 & 2 & 1.0 & 1761.2 & 9.2 & 63.7 & 0.7 \\
\hline & Galiteuthis glacialis & 3 & 9.4 & 3 & 1.6 & 211.2 & 1.1 & 24.9 & 0.3 \\
\hline \multirow{4}{*}{ 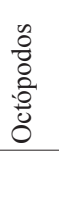 } & Pareledone turqueti & 4 & 12.5 & 4 & 2.1 & 315.2 & 1.6 & 46.4 & 0.5 \\
\hline & Papillated Pareledone & 1 & 3.1 & 2 & 1.0 & 182 & 0.9 & 6.2 & 0.1 \\
\hline & Adelieledone polymorpha & 1 & 3.1 & 1 & 0.5 & 50.4 & 0.3 & 2.4 & 0.0 \\
\hline & Total & & & 193 & 100 & 19220.2 & 100 & 9124.4 & 100 \\
\hline
\end{tabular}


While the predominance of $P$. glacialis in terms of IRI\% was constant throughout the 3 years of sampling, a substantial decrease was observed in 2004. This year coincided with a stronger contribution of Moroteuthis knipovitchi to the diet of seals, reaching a \%IRI value of 29, almost equaling $P$. glacialis (Fig. 2).

The beak size (LRL or LHL), mean estimated dorsal mantle length (ML) and mean estimated mass of the cephalopod species taken by elephant seals are shown in Table II. The log-linear analysis indicated significant differences among years in the cephalopod diet composition $(\mathrm{p}<0.05)$ with sexes also predating differentially according to this temporal variation $(\mathrm{p}<0.05)$. While octopods occurred in the diet of some male individuals, females preyed exclusively on squid taxa (Fig. 3).

Tab. II. Beak size (LRL/LHL, mm) estimated mantle length (ML, $\mathrm{mm}$ ), and estimated mass (M, $\mathrm{g}$ ) of cephalopods preyed on by juvenile southernelephant seals at Stranger Point, Isla 25 de Mayo/King George Island ( $\mathrm{n}=$ the number of lower beaks found of each taxon).

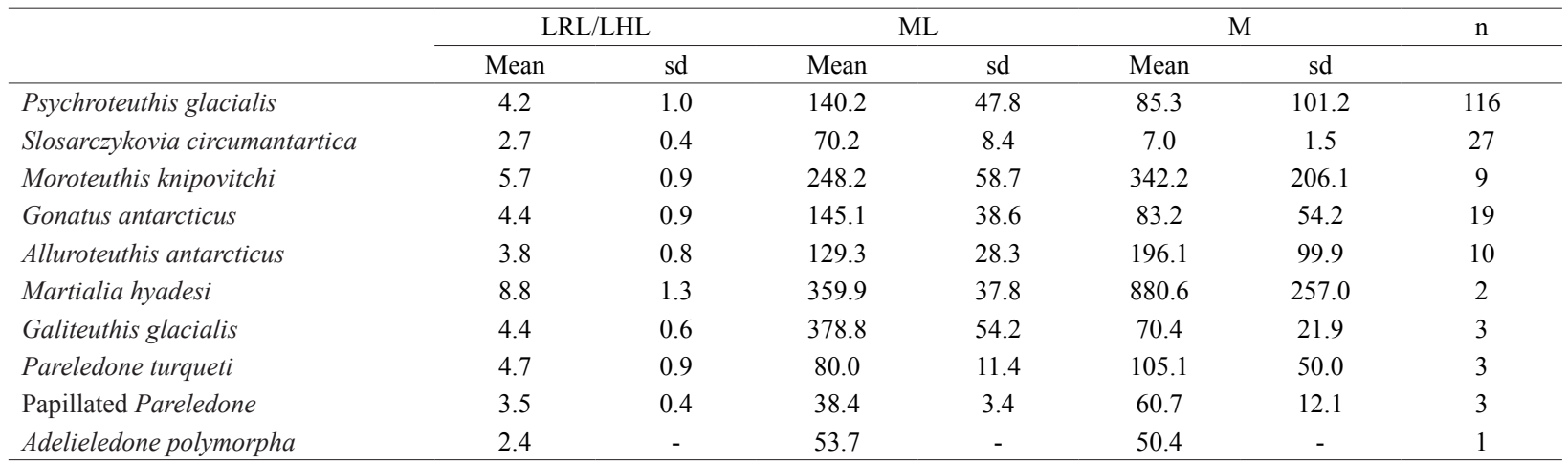

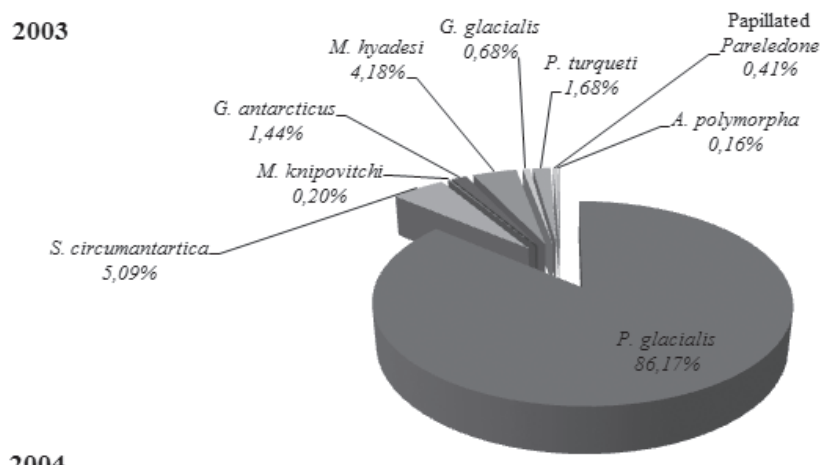

2004

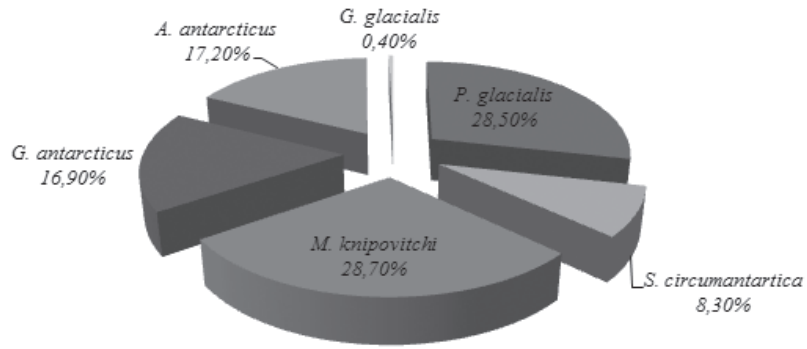

2005

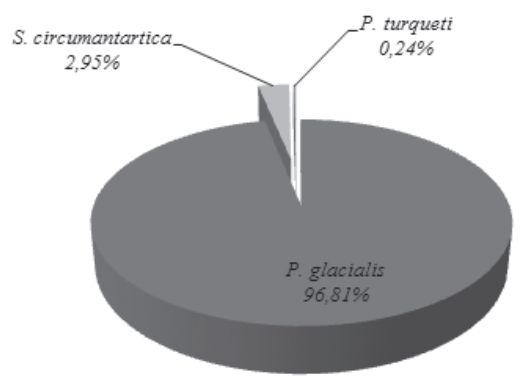

Fig. 2. Contribution of the different prey taxa of juvenile elephant seals to the total Relative Importance Index in 2003,2004 and 2005. 
Females

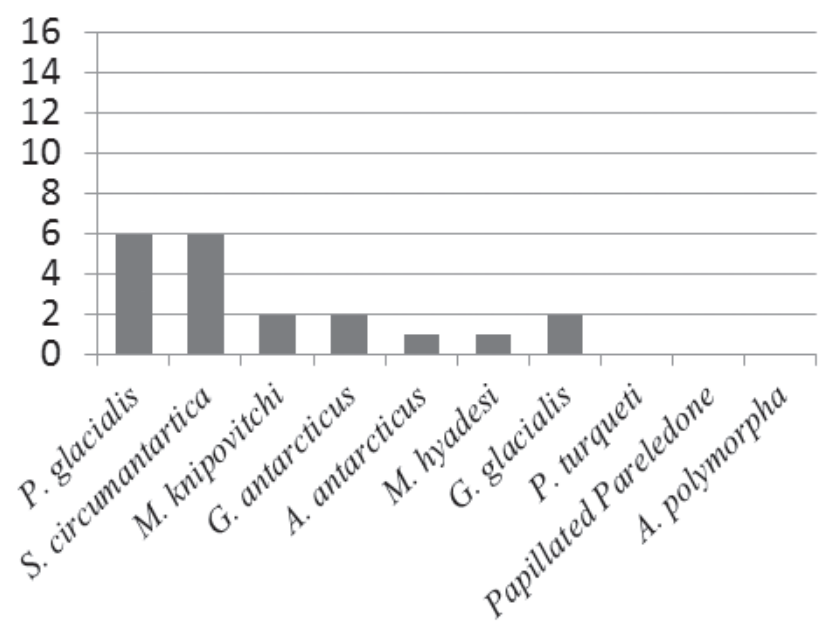

Males

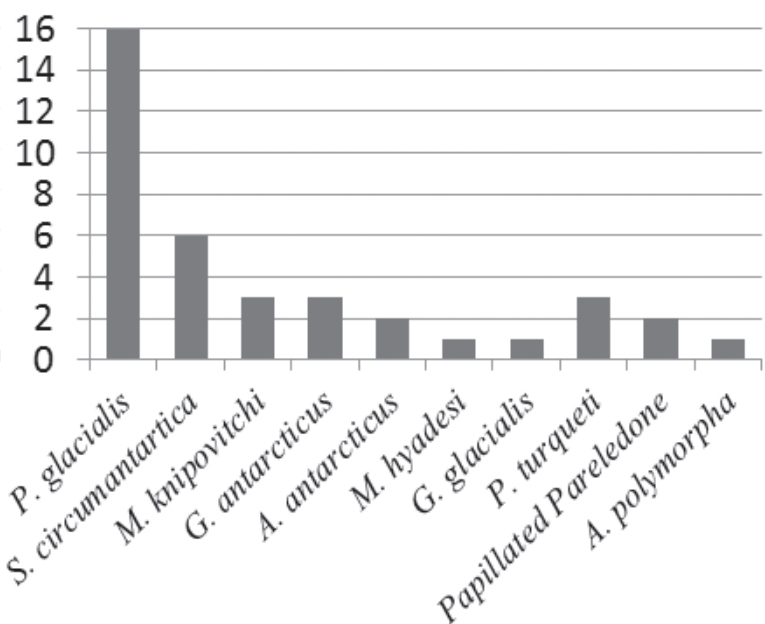

Fig. 3. Frequency of occurrence of the different cephalopod taxa preyed upon by juvenile elephant seals at I. 25 de Mayo/King George, discriminated by sex.

\section{DISCUSSION}

Of the 10 prey taxa identified, 9 have a circumantarctic distribution, south of the Antarctic Polar Front: Psychroteuthis glacialis, Slosarczykovia circumantartica, Moroteuthis knipovitchi, Gonatus antarcticus, Alluroteuthis antarcticus, Galiteuthis glacialis, Pareledoneturqueti, Papillated Pareledone and Adelieledone polymorpha (FILIPPOVA, 1972; KRISTENSEN, 1981; Lu \& StranKs, 1994; GRÖGERET al., 2000; LiPINSKI, 2001; Collins \& Rodhouse, 2006, Rodhouse et al., 2014).

Elephant seals have a quick digestion of 13 hours approximately according to KROCKENBERGER \& BRYDEN (1994). However, in several phocid species, the hard parts of prey can be retained in the stomach for at least 7 days (HARvey \& Antonelis, 1994; Tollit et al., 1997). Moreover, the swimming speed of juveniles of $M$. leonina can reach up to $100 \mathrm{~km}$ per day (FIELD et al., 2005). Hence, we assume that, at the time of sampling, food remnants that were extracted from the stomachs could well reflect prey captured at a distance of about $700 \mathrm{~km}$ from Isla $25 \mathrm{de}$ Mayo.

If we consider that: (a) The juvenile seals sampled in the present study belong to the southernmost breeding population of M. leonina; (b) studies of movements at sea by satellite tellemetry of juvenile seals from this colony had shown that most of them travelled to the southwest of the South Shetland islands and centred their foraging activities in ice free areas west of the Antarctic peninsula (BORNEMANN et al., 2000; Tosh et al., 2009). Then, the almost exclusively Antarctic distribution of their cephalopod prey taxa is probably a reflection of their foraging areas and not a bias from the sampling technique.

Notwithstanding, in 2003, two lower beaks of Martialia hyadesi were removed from the stomach contents of two seals (one male and one female). This species has a circum-Antarctic distribution associated with the Polar Frontal Zone (Gonzalez et al., 1997; GonZalez \&
Rodhouse, 1998; Collins \& Rodhouse, 2006). Moreover, Rodhouse et al. (2014) have catalogued this squid as subantarctic, extending from the Antarctic Polar Front to the Sub-Tropical Front.

The Antarctic Peninsula is one the most rapidly warming regions on earth, having experienced a $2{ }^{\circ} \mathrm{C}$ increase in the annual mean temperature and a $6^{\circ} \mathrm{C}$ rise in the mean winter temperature since 1950 (DuCKLOW et al., 2007). Moreover, delivery of heat from the Antarctic Circumpolar Current has increased significantly in the last decades, sufficient to drive to a $0.6^{\circ} \mathrm{C}$ warming of the upper $300 \mathrm{~m}$ of shelf water (STAMMERJOHN et al., 2008). Thus, it should be considered that the squid $M$. hyadesi might be (if its occurrence in the diet of M. leonina increases) expanding its spatial niche to higher latitudes. Another explanation might be associated to more northerly feeding grounds of juveniles which may reach the Antarctic Polar Front or even further north. In this regard BORNEMANN et al. (2000) reported one juvenile (underyearling) elephant seal from Isla 25 de Mayo which traversed the Drake Passage and almost reached the patagonian shelf when the satellite transmitter failed.

In the present study, the squid $P$. glacialis proved to be the most important prey in terms of frequency of occurrence, numerical abundance, biomass and relative importance index (Tab. I). These results are in line with previous information on food habits of $M$. leonina from Isla 25 de Mayo/King George (DANERI et al., 2000, 2005). Significant differences were found between years in the cephalopod diet composition of seals. Moreover, a differential response of female and male individuals to this temporal variation was observed. While satellite telemetry studies have not indicated sexual segregation in the foraging areas of juvenile males and females of this colony (Bornemann et al., 2000), DANERI et al. (2000, 2014) reported gender differences in the cephalopod diet of the adult component of the population, with octopod prey becoming more important in males. 
The interannual differences observed in the composition of the diet of juveniles of M. leonina could be linked to temporal changes in the availability of prey, mainly krill (Euphausia superba) in the feeding areas. Euphausiids are a common food item of some of the squid prey species identified in this study, mainly $P$. glacialis (Coluins \& Rodhouse, 2006). In this regard, Hewitt et al. (2003) estimated intra and interannual variations in the density and spread of krill biomass, E. superba, inferred from acoustic surveys on areas near the South Shetland between the summers of 1991/92 to 2001/02. These authors found that in the 1991/92 and 1997/98 seasons (coinciding with the Southern Oscillation event of "El Niño") the recruitment of krill from laying eggs was very low and the krill biomass density declined sharply over these two periods as in subsequent years. It should also be noted that PiatKowski et al. (2002), analyzing the temporal variation in the cephalopod diet of adult females of M. leonina from this same colony, indicated that the contribution of the squid $P$. glacialis to their diet, was proportionately less during events of "El Niño". Moreover, they suggested an increase availability of this squid species to females on the Bellingshausen Sea area concomitantly with a decrease in the temperature of the sea surface associated with "La Niña" events. All these findings fit well to the results of this study since the marked decrease in the contribution of $P$. glacialis to the diet of juveniles of $M$. leonina was observed in conjunction with a warm episode of El Niño Southern oscillation which occurred in 2004 (Tab. III). Notwithstanding, it is of major importance to continue monitoring the diet of M. leonina from Isla 25 de Mayo for a longer period of time (ideally a decade) to assess more precisely the possible existence of a correlation between oceanographic and climatic changes in the Southern Ocean resulting from the "El Niño Southern Oscillaton" and the feeding pattern of the different components of the population of this colony.

Tab. III. Indicated in bold are warm episodes of the ENSO based on a threshold of $+/-0.5^{\circ} \mathrm{C}$ for the Oceanic Niño Index (ONI) [3 month running mean of ERSST.v3b SST anomalies (Sмiтн et al., 2008) in the Niño 3.4 region $\left.\left(5^{\circ} \mathrm{N}-5^{\circ} \mathrm{S}, 120^{\circ}-170^{\circ} \mathrm{W}\right)\right]$. The box include the sampling period covered by this study (Source: http://www.cpc.ncep.noaa).

\begin{tabular}{cccccccccccccc}
\hline Year & DJF & JFM & FMA & MAM & AMJ & MJJ & JJA & JAS & ASO & SON & OND & NDJ \\
\hline 2002 & -0.2 & 0.0 & 0.1 & 0.3 & $\mathbf{0 . 5}$ & $\mathbf{0 . 7}$ & $\mathbf{0 . 8}$ & $\mathbf{0 . 8}$ & $\mathbf{0 . 9}$ & $\mathbf{1 . 2}$ & $\mathbf{1 . 3}$ & $\mathbf{1 . 3}$ \\
2003 & $\mathbf{1 . 1}$ & $\mathbf{0 . 8}$ & 0.4 & 0.0 & -0.2 & -0.1 & 0.2 & 0.4 & 0.4 & 0.4 & 0.4 & 0.3 \\
2004 & 0.3 & 0.2 & 0.1 & 0.1 & 0.2 & 0.3 & $\mathbf{0 . 5}$ & $\mathbf{0 . 7}$ & $\mathbf{0 . 8}$ & $\mathbf{0 . 7}$ & $\mathbf{0 . 7}$ & $\mathbf{0 . 7}$ \\
2005 & $\mathbf{0 . 6}$ & 0.4 & 0.3 & 0.3 & 0.3 & 0.3 & 0.2 & 0.1 & 0.0 & -0.2 & -0.5 & -0.8 \\
2006 & -0.9 & -0.7 & -0.5 & -0.3 & 0.0 & 0.1 & 0.2 & 0.3 & $\mathbf{0 . 5}$ & $\mathbf{0 . 8}$ & $\mathbf{1 . 0}$ & $\mathbf{1 . 0}$ \\
\hline
\end{tabular}

Acknowledgments. We are indebted to Dr. E. Marschoff for his statistical advice. We are also grateful to Dr Nestor Coria, Dr Maria Busch and Dr Roberto Bo who critically commented the manuscript. This work was funded by the Dirección Nacional del Antártico and the Agencia Nacional de Promoción Científica y Tecnológica (Grants: Picto $\left.\mathrm{N}^{\circ} 11559-36054\right)$. Our procedures conform to the Code of Ethics of Animal Experimentation in Antarctica. The permit for this work was granted by the Dirección Nacional del Antártico (Environmental Office), Argentina.

\section{REFERENCES}

Biuw, M.; Boehme, L.; Guinet, C.; Hindell, M.; Costa, D.; Charrassin, J. B. \& Roquet, F. 2007. Variations in Behavior and Condition of a Southern Ocean Top Predator in Relation to in Situ Oceanographic Conditions. Proceedings of the National Academy of Sciences 104(34):13705-13710.

Bornemann, H.; Kreyscher, S.; Ramdohr, S.; Martin, T.; Carlini, A.; Sellmann, L. \& Plotz, J. 2000. Southern elephant seal movements and Antarctic sea ice. Antarctic Science 12:3-15.

Bost, C. A.; Cotté, C.; Bailleul, F.; Cherel, Y.; Charrassin, J. B.; Guinet, C.; Ainley, D. G. \& Weimerskirch, H. 2009. The Importance of Oceanographic Fronts to Marine Birds and Mammals of the Southern Oceans. Journal of Marine Systems 78(3):363-376.

Boyd, I. L., Arnbom T. A. \& FedaK M. A. 1994. Biomass and energy consumption of the South Georgia population of southern elephant seals. In: Le Boeuf, B. J. \& Laws, R. M. eds. Elephant seals: population ecology, behavior, and physiology. Berkeley, University of California Press, p.98-117.

Boyd, I. L.; WAlker, T. R. \& Poncet, J. 1996. Status of Southern Elephant Seals at South Georgia. Antarctic Science 8(3):237-244.

Bradshaw, C. J. A.; Hindell, M. A.; Best, N. J.; Phillips, K. L.; Wilson, G. \& Nichols, P. D. 2003. You Are What You Eat: Describing the Foraging Ecology of Southern Elephant Seals (Mirounga leonina) Using Blubber Fatty Acids. Proceedings of the Royal Society of London, Series B: Biological Sciences 270(1521):1283-1292.
Burton, H. R.; Arnbom, T.; Boyd, I. L.; Bester, M. V. \& Wilkinson, I. 1997. Significant differencies in weaning mass of southern elephant seals from five sub-Antarctic islands in relation to population declines. In: Battaglia, B.; Valencia, J. \& Walton, D. W. H. eds. Antarctic communities. Species, structure and survival. Cambridge, Cambridge University Press, p.335-341.

Carlini, A. R.; Poljak, S.; Daneri G. A.; Márquez, M. E. I. \& Negrete, J. 2006. The dynamics of male harem dominance in southern elephant seals (Mirounga leonina) at the South Shetland Islands. Polar Biology29:796-805.

CLARKE, M. R. ed. 1986. A handbook for the identification of cephalopod beaks. Oxford, Clarendon Press. 273p.

Clarke, M. R. \& MacLeod, N. 1982. Cephalopods in the Diet of Elephant Seals at Signy Island, South Orkney Islands. British Antarctic Survey Bulletin 57:27-31.

Collins, M. A. \& Rodhouse, P. G. 2006. Southern ocean cephalopods. Advances in Marine Biology 50:191-265.

CORTÉs, E. 1997. A critical review of methods of studying fish feeding based on analysis of stomach contents: application to elasmobranch fishes. Canadian Journal of Fisheries and Aquatic Science 54:726738.

Croxall, J. P.; Prince, P. A. \& Ricketts, C. 1985. Relationships between prey life-cycles and the extent, nature and timing of seal and seabird predation in the Scotia Sea. Marine Ecology Progress Series 58:3-16.

DANERI, G. A. \& CARLini, A. 2002. Fish prey of southern elephant seals, Mirounga leonina, at King George Island. Polar Biology 25(10):739743.

1996. Stomach flushing: An adequate non lethal method for the study of elephant seal's diet. Contribución del Instituto Antártico Argentino 452:7.

Daneri, G. A.; Carlini A. R. \& Rodhouse, P. G. 2000. Cephalopod Diet of the Southern Elephant Seal, Mirounga leonina, at King George Island, South Shetland Islands. Antarctic Science 12(1):16-19.

Daneri, G. A.; Carlini, A. R.; Hernandez, C. M. \& Harrington, A. 2005. The diet of Antarctic fur seals, Arctocephalus gazella, at 
King George Island, during the summer-autumn period. Polar Biology 28(4):329-333.

Ducklow, H.W.; Baker, K.; Martinson, D. G.; Quetin, L. B.; Ross, R. M.; Smith, R. C.; Stammerjohn, S. E.; Vernet, M. \& Fraser, W. R. 2007. Marine pelagic ecosystems: The West Antarctic Peninsula. Philosophical Transactions of the Royal Society of London B 362:67-94.

Field, I. C.; Bradshaw, C. J. A.; Burton, H. R.; Sumner, M. D. \& Hindell, M. A. 2005. Resource Partitioning through Oceanic Segregation of Foraging Juvenile Southern Elephant Seals (Mirounga leonina). Oecologia 142(1):127-135.

Field, I. C.; Bradshaw, C. J. A.; van den Hoff, J.; Burton, H. R. \& Hindell, M. A. 2007. Age-related shifts in the diet composition of southern elephant seals expand overall foraging niche. Marine Biology 150(6):1441-1452.

Filippova, J. A. 1972. New data on the squids (Cephalopoda: Oegopsida) from the Scotia Sea (Antarctic). Malacologia 11(2):391-406.

González, A. F.; Trathan, P. N.; Yau, C. \& Rodhouse, P. G. 1997. Interactions between oceanography, ecology and fishery biology of the ommastrephid squid Martialia hyadesi in the South Atlantic. Marine Ecology Progress Series 152:205-215.

Gonzalez, A. F. \& Rodhouse, P. G. 1998. Fishery biology of the seven star flying squid Martialia hyadesi at South Georgia during winter. Polar Biology 19(4):231-236.

Green, K. \& Burton, H. R. 1993. Comparison of the stomach contents of southern elephant seals, Mirounga leonina, at Macquarie and Heard Islands. Marine Mammal Science 9(1):10-22.

Gröger, J.; Piatkowski U. \& Heinemann H. 2000. Beak length analysis of the Southern Ocean squid Psychroteuthisglacialis (Cephalopoda: Psychroteuthidae) and its use for size and biomass estimation. Polar Biology 23(1):70-74.

Guinet, C.; Juventine, P. \& Weimerskirch, H. 1999. Recent population change of the southern elephant seal at lies Crozer and Iles Kerguelen: the end of the decrease?. Antarctic Science 11:193-197.

Harvey, J. T. \& Antonelis, G. A. 1994. Biases associated with non-lethal methods of determining the diet of northern elephant seals. Marine Mammal Science 10(2): 178-187.

Hewitt, R. P.; Demer, D. A. \& Emery, J. H. 2003. An 8-year cycle in krill biomass density inferred from acoustic surveys conducted in the vicinity of the South Shetland Islands during the austral summers of 1991/92 through 2001/2002. Aquatic Living Resource 16:205-213.

Hindell, M. A. \& Burton, H. R. 1987. Past and Present Status of the Southern Elephant Seal (Mirounga leonina) at Macquarie Island. Journal of Zoology 213(2):365-580.

Hindell, M. A. \& McMahon, C. R. 2000. Long distance movement of a southern elephant seal (Mirounga leonina) from Macquarie Island to Peter 1. Marine Mammal Science 16(2):504-507.

Hindell, M. A.; Bradshaw, C. J. A.; Sumner, M. D.; Michael, K. J. \& Burton, H. R. 2003. Dispersal of female southern elephant seals and their prey consumption during the austral summer: relevance to management and oceanographic zones. Journal of Applied Ecology 40(4):703-715.

Hindell, M. A.; Slip, D. J. \& Burton, H. R. 1994. Possible Causes of the Decline of Southern Elephant Seal Populations in the Southern Pacific and Southern Indian Oceans. In: Le Boeuf, B. J. \& Laws, R. M. Elephant seals: population ecology, behaviour and physiology. Berkeley, University of California Press, p. 66-84.

Hindell, M. A.; Slip, D. J.; Burton, H. R. \& Bryden, M. M. 1992. Physiological implications of continuous, prolonged, and deep dives of the southern elephant seal (Mirounga leonina). Canadian Journal of Zoology 70(2):370-379.

Hoelzel, R.; Campagna, C. \& Arnbom, T. 2001. Genetic and Morphometric Differentiation between Island and Mainland Southern Elephant Seal Populations. Proceedings of the Royal Society of London, Series B: Biological Sciences 268(1464):325-332.

Hunt, J. G. L.; Mehlum, F.; Russell, R. W.; Irons, D.; Decker, M. B. \& BeCKeR, P. H. 1999 Physical processes, prey abundance, and the foraging ecology of seabirds. Proceedings of the International Ornithological Congress 22:2040-2056.

Knox, G. A. 1994. The biology of the Southern Ocean. Antarctic Science 7:213-214.
Kristensen, T. K. 1981. The genus Gonatus Gray, 1849 (Mollusca: Cephalopoda) in the North Atlantic: a revision of the North Atlantic species and description of Gonatussteenstrupi n. sp. Steenstrupia 7(4):61-99.

Krockenberger, M. B. \& Bryden, M. M. 1994. Rate of passage of digesta through the alimentary tract of southern elephant seals (Miroungaleonina)(Carnivora: Phocidae). Journal of Zoology 234(2):229-237.

Laws, R. M. 1994. History and present status of Southern Elephant Seal populations. University of California Press, Berkeley, Elephant seals: population ecology, behavior, and physiology:49-65.

Le Boeuf, B. J. \& Laws, R. M. 1994. Elephant Seals: An introduction to the genus. 1994. University of California Press, Los Angeles, Elephant seals, population ecology, behavior and physiology:1-28.

Lima, I. D.; Olson, D. B. \& Doney, S. C. 2002. Biological response to frontal dynamics and mesoscale variability in oligotrophic environments: biological production and community structure. Journal of Geophysical Research 107(C8):3111.

Ling, J. K. \& Bryden, M. M. 1992. Mirounga leonina. Mammalian Species 391:1-8.

LipINSKI, M. R. 2001. Preliminary description of two new species of Cephalopods (Cephalopoda: Brachioteuthidae) from South Atlantic and Antarctic waters. Bulletin of the Sea Fisheries Institute 1(152):3-14.

Lu, C. C. \& Stranks, T. N. 1994. Synopsis of Pareledone and Megaleledone species, with description of two new species from East Antarctica (Cephalopoda: Octopodidae). Memoirs of Museum Victoria 54:221-242.

Mann, K. H. \& LAZIER, J. R. N. eds. Dynamics of Marine Ecosystems. Boston, Blackwell Science Malden. 492p.

McCANN, T. S. 1985. Size, status and demography of Southern Elephant Seal (Mirounga leonina) populations. Studies of sea mammals in south latitudes. South Australian Museum 1-17.

McConnell, B. J.; Chambers, C. \& Fedak, M. A. 1992. Foraging ecology of Southern Elephant Seals in relation to the bathymetry and productivity of the Southern Ocean. Antarctic Science 4:393-398.

McMahon, C. R.; Burton, H. R. \& Bester, M. N. 2003. A demographic comparison of two Southern Elephant Seal populations. Journal of Animal Ecology 72(1):61-74.

Newland, C. B.; Field, I. C.; Nichols, P. D.; Bradshaw, C. J. A. \& Hindell, M. A. 2009. Blubber fatty acid profiles indicate dietary resource partitioning between adult and juvenile southern elephant seals. Marine Ecology Progress Series 384:303-312.

Okutani, T. \& Clarke, M. R. eds. Identification key and species description for Antarctic squids. BIOMASS. v. 21.

Pakhomov, E. A.; Perissinotto, R. \& McQuaid, C. D. 1994. Comparative structure of the macrozooplankton/micronekton communities of the Subtropical and Antarctic Polar Fronts. Marine Ecology Progress Series 111(1):155-169.

Piatkowski, U.; Vergani, D. F. \& Stanganelli, Z. B. 2002. Changes in the cephalopod diet of southern elephant seal females at King George Island, during El Nino-La Nina events. Journal of the Marine Biological Association of the United Kingdom 82(5):913-916.

Pollard, R. T.; Bathmann, U.; Dubischar, C.; Read, J. F. \& Lucas, M. 2002. Zooplankton distribution and behaviour in the Southern Ocean from surveys with a towed optical plankton counter. Deep Sea Research Part II: Topical Studies in Oceanography 49(18):38893915.

ReID, K. 1995 The diet of Antarctic fur seals (Arctocephalus gazella, Peters 1875) during winter at South Georgia. Antarctic ScienceInstitutional Subscription 7(3):241-250.

Rodhouse, P. G.; Pince, P. A.; Clarke, M. R. \& Murray, A. W. A. 1990. Cephalopod prey of the grey-headed albatros: Diomedea chrysostoma. Marine Biology 104(3):353-362.

Rodhouse, P. G.; Arnbom, T. R.; Fedak, M. A.; Yeatman, J. \& Murray, A. W. A. 1992. Cephalopod prey of the Southern Elephant Seal, Mirounga leonina L. Canadian Journal of Zoology 70(5):10071015.

Rodhouse, P. G.; H. Griffiths \& XaVier, J. C. 2014. Southern Ocean squid. In: De Broyer, C.; Koubbi, P.; Griffiths, H. J.; Raymond, B.; Udekem d'Acoz, C. D'; Van de Putte, A. P.; Danis, B.; David, 
B.; Grant, S.; Gutt, J.; Held, C.; Hosie, G.; Huettmann, F.; Post, A.; Ropert-Coudert, Y. eds. Biogeographic Atlas of the Southern Ocean. Cambridge, Scientific Committee on Antarctic Research, p. $284-289$.

S.C.A.R. 2002. Reporte de la 27a Reunión del Comité Científico sobre Investigaciones Antárticas. Shangai, China.

S.C.A.R. 2006. Reporte de la 29a Reunión del Comité Científico sobre Investigaciones Antárticas. Hobart, Tasmania, Australia.

Slade, R. W.; Moritz, C.; Hoelzel, A. R. \& Burton, H. R. 1998. Molecular population genetics of the Southern Elephant Seal Mirounga leonina. Genetics 149(4): 1945-1957.

SLIP, D. J. 1995. The Diet of Southern Elephant Seals (Mirounga leonina) from Heard Island. Canadian Journal of Zoology 73(8):1519-1528.

Smetacek, V. \& Nicol, S. 2005. Polar Ocean ecosystems in a changing world. Nature 437(7057):362-68.

Smith, T. M.; Reynolds, R. W.; Peterson, T. C. \& Lawrimore, J. 2008. Improvements NOAAs Historical Merged Land-Ocean Temp Analysis (1880-2006). Journal of Climate 21:2283-2296.
Stammerjohn, S. E.; Martinson, D. G.; Smith, R. C.; Yuan, X. \& Rind, D. 2008. Trends in Antarctic annual sea ice retreat and advance and their relation to ENSO and Southern Annular Mode Variability. Journal of Geophysical Research 113(3):90.

Tollit, D. J.; Steward, M. J.; Thompson, P. M.; Pierce, G. J.; Santos, M. B. \& Hughes, S. 1997. Species and size differences in the digestion of otoliths and beaks: implications for estimates of pinniped diet composition. Canadian Journal of Fisheries and Aquatic Sciences 54(1):105-119.

Tosh, C. A.; Bornemann, H.; Ramdohr, S.; Schroder, M.; Martin, T.; Carlini, A.; Plotz, J. \& Bester, M. N. 2009. Adult male southern elephant seals from King George Island utilize the Weddell Sea. Antarctic Science 21(2):113-121.

van DEN Hoff, J. H. B. \& Davies, R. 2003. Diet of male southern elephant seals (Mirounga leonina L.) hauled out at Vincennes Bay, East Antarctica. Polar Biology 26(1):27-31.

XAVIER, J. C. \& Cherel, Y. eds. Cephalopod beak guide for the Southern Ocean. British Antactic Survey. 129p. 